\title{
Tourist development and the environment: the case of Cephalonia and Ithaca
}

\author{
D. G. Prokopiou ${ }^{1}$, B. S. Tselentis ${ }^{1} \&$ D. Bousbouras ${ }^{2}$ \\ ${ }^{1}$ Department of Maritime Studies, University of Piraeus, Greece \\ ${ }^{2}$ Hellenic Ornithological Society, Greece
}

\begin{abstract}
The tourist industry is one of the most important economic activities in Greece. The country receives over 14 million visitors per year, thus managing to double its population within the peak season. These numbers no doubt create some speculation as to the quality of the tourist product offered, but more importantly, concern is expressed by many, as to the impacts on environmental health and ecosystem stability. Many researches and scientists, over recent years, have studied the environmental impacts of tourist development, since it is well documented that when tourist development exceeds the capacity of the natural environment, many adverse effects arise, thus undermining the very substance of the tourist trade and associated services. Tourist development requires a multi disciplinary approach, since it is a function of various issues, such as natural resources and ecosystems management, the effects of human activities on fauna, flora and the coastal zone, economic and social aspects etc.

For the Greek Islands, the environment, both natural and man made, plays a vital role for the sustainable development of the industry. The purpose of this paper is to apply the principles of carrying capacity assessment to Cephalonia and Ithaca islands in an effort to highlight the importance of such a tool in developing long-term sustainable policies for such communities.
\end{abstract}

\section{Introduction}

The World Tourism Organisation (WTO) proposes the following definition of carrying capacity: "The maximum number of people that may visit a tourist destination at the same time, without causing destruction to the physical, economic, socio-cultural environment and an unacceptable decrease in the quality of visitors' satisfaction" [1]. 
Today, controlling tourist growth has become a central policy issue for the tourist trade [2], and it is noteworthy that carrying capacity assessment has become an important tool for facilitating planning and developing policy issues for the industry. [3] Cephalonia and Ithaca islands attract over 200 thousand tourist visitors per year.

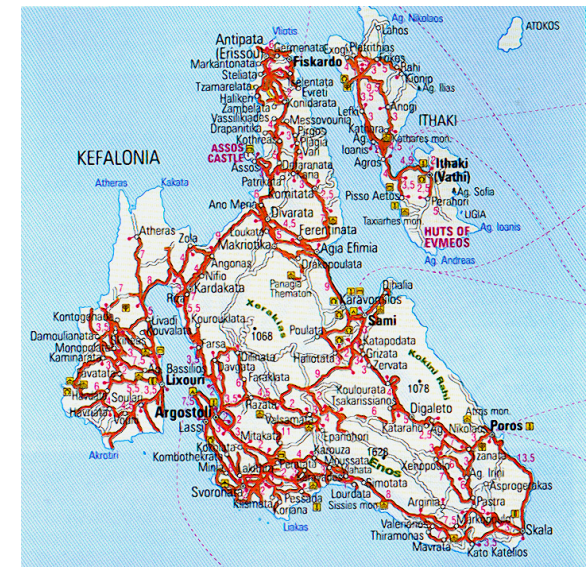

Figure 1: $\quad$ Map of Cephalonia and Ithaca [4].

Cephalonia is the largest of the Ionian Islands, with a total area of 688 square kilometres. It lies to the south of Lefkada and Ithaka and to the north of Zakitnhos opposite the western entrance to the Gulf of Corinth. The coastline of Cephalonia totals more than 250 kilometers. The highest mountain is Ainos, which boasts a unique dense black-fir forest, which has been designated as a national park. [5]

Ithaca is a small island in the Ionian Sea with an area of 96 square kilometers [6]. The coastline of Ithaca is 101 kilometers.

Relevant carrying capacity indicators have been developed and categorised into three groups: 1. physical-ecological, 2. infrastructural and 3. Sociologicalpsychological [7]. The purpose of this paper is to try and attain values for these indicators and integrate them into the planning process of the Greek tourist business [8].

\section{Basic population characteristics for Cephalonia and Ithaca}

\subsection{Population trends, Hellas, Ionian islands and Cephalonia}

The data presented in Table 1 indicates that $30 \%$ of the island's residents reside in the capital Argostoli, thus giving the municipality of Argostoli the highest inhabitant density for Cephalonia. Table 2 shows that the population of the Prefecture of Cephalonia has increased during the period of 1971-2001. This increase in population is more pronounced for the towns of Argostoli, Livathous and Sami where many tourism businesses are based. 
Table 1: $\quad$ Population data for the prefecture of Cephalonia.

\begin{tabular}{|l|c|l|l|}
\hline \multicolumn{4}{|c|}{ POPULATION CHARACTERISTICS (2001) } \\
\hline Municipality & Population & $\begin{array}{l}\text { Area } \\
\left(\mathrm{km}^{2}\right)\end{array}$ & $\begin{array}{l}\text { Density } \\
\text { inhabitants } / \mathrm{km}^{2}\end{array}$ \\
\hline Argostoli & 12.589 & 157,670 & 79,84 \\
\hline Eleou Pronon & 3.840 & 111,687 & 34,38 \\
\hline Erisou & 1.963 & 78,114 & 25,13 \\
\hline Livathous & 4.663 & 62,626 & 74,46 \\
\hline Palikis & 7.836 & 119,341 & 62,66 \\
\hline Pilareon & 1.565 & 81,112 & 19,29 \\
\hline Sami & 2.895 & 129,326 & 22,39 \\
\hline Community of Omaloi & 1.053 & 46,699 & 22,55 \\
\hline Cephalonia island & 39.488 & 786.575 & 50,20 \\
\hline Ithaca island & 3.084 & 117,812 & 26,18 \\
\hline Prefecture of Cephalonia & 42.572 & 904,387 & 50,39 \\
\hline
\end{tabular}

Table 2: $\quad$ Population history, prefecture of Cephalonia.

\begin{tabular}{|c|c|c|c|c|c|c|c|}
\hline \multicolumn{7}{|c|}{ POPULATION CHARACTERISTICS AND TRENDS (1971-2001) } \\
\hline \multirow{2}{*}{ Municipalities } & \multicolumn{3}{|c|}{ Population/inhabitants } & \multicolumn{3}{c|}{ Population/Trends } \\
\cline { 2 - 8 } & 1971 & 1981 & 1991 & 2001 & $1971-81$ & $1981-91$ & $1991-01$ \\
\hline Argostoli & 9796 & 9129 & 9918 & 12589 & $-0,68$ & 0,86 & 2,69 \\
\hline Eleiou Pronon & 4382 & 2972 & 3275 & 3840 & $-3,22$ & 1,02 & 1,73 \\
\hline Erisoou & 1605 & 1470 & 1645 & 1963 & $-0,84$ & 1,19 & 1,93 \\
\hline Livathous & 3997 & 3446 & 3831 & 4663 & $-1,38$ & 1,12 & 2,17 \\
\hline Palikis & 7556 & 6277 & 6432 & 7836 & $-1,69$ & 0,25 & 2,18 \\
\hline Sami & 2189 & 2343 & 2258 & 2895 & 0,70 & $-0,36$ & 2,82 \\
\hline Pilareon & 1175 & 1093 & 1172 & 1565 & $-0,70$ & 0,72 & 3,35 \\
\hline Community of Omaloi & 1090 & 919 & 861 & 1053 & $-1,57$ & $-0,63$ & 2,23 \\
\hline Cephalonia island & 31.790 & 27.649 & 29.392 & 36.404 & $-13 \%$ & $6 \%$ & $23 \%$ \\
\hline Ithaca island & 4162 & 3648 & 3082 & 3084 & $-1,23$ & $-1,55$ & 0,01 \\
\hline Prefecture of Cephalonia & 35952 & 31297 & 32474 & 39488 & $-1,29$ & 0,38 & 2,16 \\
\hline
\end{tabular}

\section{Tourist indicators}

\subsection{Tourist hospitality enterprises and tourist development}

Tourist development in Cephalonia started in the early ' 80 s, whereas in Ithaca it was not until the 90's. All development data are presented in Table 3.

In Cephalonia and Ithaca, over the last years 6 small hotels have closed down. We must note at this point, that the tourist industry in Cephalonia is moving steadily towards small units offering high quality services thus attracting high income tourists. The question as to the relationship between size and quality, however, still remains, especially in trying to convince businessmen that the emphasis should be on higher quality and not higher numbers.

\subsection{Tourist capacity, arrivals and visitors}

Unfortunately the official data do not represent the real tourist capacity, as is the case for other destinations in Greece. The data collected and presented in this paper was thus collated though ground collection exercises with the use of questionnaires and local visits. The estimated tourist infrastructure available and operable in Cephalonia and Ithaca is presented in Table 6. 
Table 3: $\quad$ Bed capacity in Cephalonia and Ithaca in relation to area and local population.

\begin{tabular}{|l|c|c|c|c|l|}
\hline \multicolumn{6}{|c|}{ BED CAPACITY IN CEPHALONIA AND ITHACA (2008) } \\
\hline Municipalities & Hotels & $\begin{array}{c}\text { Hotel's } \\
\text { beds }\end{array}$ & $\begin{array}{c}\text { Other hospitality } \\
\text { enterprises }\end{array}$ & $\begin{array}{l}\text { Total } \\
\text { beds }\end{array}$ & $\begin{array}{l}\text { Density } \\
\text { beds/ } \mathrm{km}^{2}\end{array}$ \\
\hline Argostoli & 26 & 2.386 & 2.889 & 5.275 & 33,45 \\
\hline Eleiou Pronon & 32 & 2.014 & 3037 & 5.051 & 45,22 \\
\hline Erisoou & 10 & 432 & 835 & 1.267 & 16,22 \\
\hline Livathous & 24 & 1.478 & 2.787 & 4.265 & 68,10 \\
\hline Palikis & 15 & 1.889 & 1.092 & 2.981 & 24,98 \\
\hline Sami & 10 & 592 & 771 & 1.363 & 10,54 \\
\hline Pilareon & 6 & 0 & 600 & 791 & 9,75 \\
\hline Community of Omaloi & 0 & 0 & 25 & 25 & 0,54 \\
\hline Cephalonia island & 123 & 8.986 & 12.032 & 21.018 & 26,72 \\
\hline Ithaca island & 5 & 195 & 959 & 1.154 & 9,80 \\
\hline Prefecture of Cephalonia & 128 & 9.181 & 12.991 & 22.172 & 24,52 \\
\hline
\end{tabular}

Table 4: $\quad$ Estimated tourist infrastructure.

\begin{tabular}{|c|c|c|}
\hline \multicolumn{3}{|c|}{ BED CAPACITY IN CEPHALONIA AND ITHACA } \\
\hline & Estimated total tourist capacity in beds & Beds per sq kilometre \\
\hline Cephalonia & 28.000 & 35,60 \\
\hline Ithaca & 1.300 & 11,03 \\
\hline
\end{tabular}

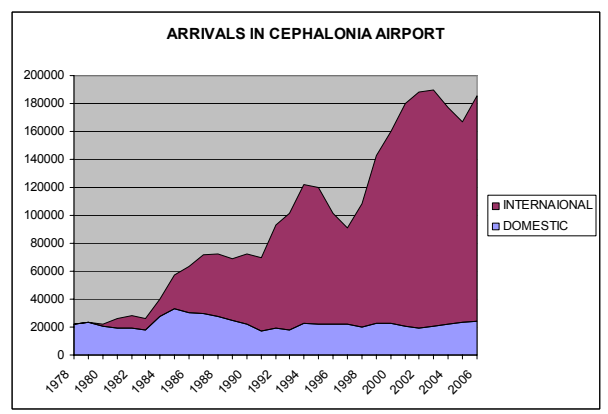

Figure 2: $\quad$ Arrivals in Cephalonia Airport.

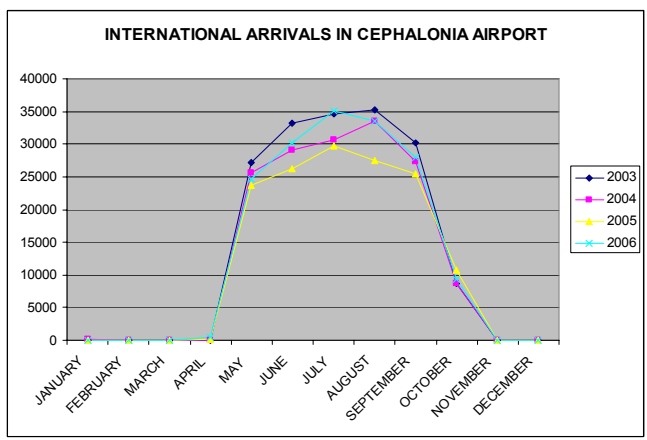

Figure 3: International arrivals in Cephalonia Airport. 
Total airport arrivals are presented in Figure 2. From 1980 international and domestic arrivals has risen considerably. The tourist season is mainly during the months of May to September.

\subsection{Tourist development as hotel beds and units}

Table 5: $\quad$ Tourist development in the Ionian islands.

\begin{tabular}{|c|c|c|c|}
\hline \multicolumn{3}{|c|}{ TOURIST DEVELOPMENT IN IONIAN ISLANDS (HOTEL'S BEDS) } \\
\hline Prefectures & 1991 & 1996 & 2001 \\
\hline Corfu & 30.381 & 36.732 & 37.001 \\
\hline Lefkas & 1.447 & 2.904 & 3.620 \\
\hline Cephalonia & 3.658 & 5.857 & 6.235 \\
\hline Zakinthos & 6.759 & 11.945 & 16.642 \\
\hline Summary for Ionian islands & 42.245 & 57.438 & 63.498 \\
\hline
\end{tabular}

Table 6: $\quad$ Hotel beds - trends in Cephalonia and Ithaca.

\begin{tabular}{|c|c|c|c|}
\hline \multicolumn{4}{|c|}{ TOURIST DEVELOPMENT IN CEPHALONIA AND ITHACA (Hotel beds) } \\
\hline & 1965 & 1969 & 1977 \\
\hline Cephalonia & 33 & 141 & 1.471 \\
\hline Ithaca & 0 & 36 & 107 \\
\hline
\end{tabular}

Table 7: $\quad$ Hotel units - trends in Cephalonia and Ithaca.

\begin{tabular}{|c|c|c|c|c|c|c|}
\hline \multicolumn{7}{|c|}{ TOURIST DEVELOPMENT IN CEPHALONIA AND ITHACA (Hotel units) } \\
\hline & 1969 & 1973 & 1978 & 1987 & 1998 & 2008 \\
\hline Cephalonia & 5 & 11 & 19 & 35 & 87 & 92 \\
\hline Ithaca & 3 & 2 & 3 & 2 & 4 & 3 \\
\hline
\end{tabular}

\section{Environmental indicators}

Ainos Mountain situated towards the south of the island, near the capital Argostoli, is considered the most environmentally important area of the island. The sea surrounding Cephalonia is the home and breeding areas for whales, dolphins and seals.

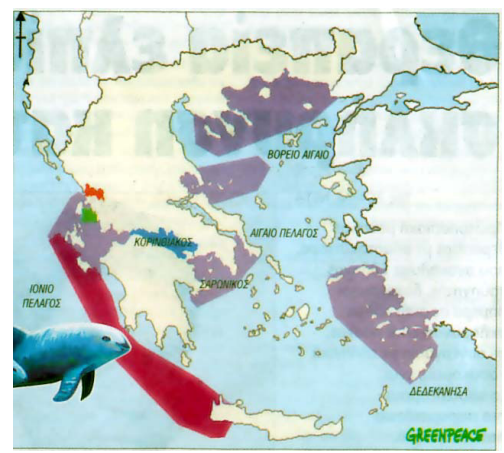

Figure 4: $\quad$ Important areas for whales and dolphins in the Greek Seas [9]. 


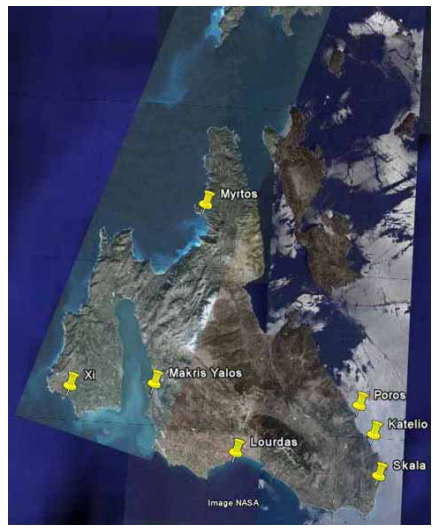

Figure 5: Blue flags for beaches in Cephalonia and Ithaca [10].

Table 8: $\quad$ Beach impact factor for Cephalonia and Ithaka.

\begin{tabular}{|c|c|c|c|c|c|c|c|}
\hline \multicolumn{7}{|c|}{ BEACH IMPACT FACTOR IN CEPHALONIA AND ITHACA } \\
\hline Municipalities & $\begin{array}{c}\text { Beach } \\
\text { length } \\
(\mathrm{km})\end{array}$ & Inhabitants & $\begin{array}{c}\text { Hotel } \\
\text { beds }\end{array}$ & $\begin{array}{c}\text { Rooms to } \\
\text { let } \\
\text { beds)[11] }\end{array}$ & $\begin{array}{c}\text { Total } \\
\text { beds }\end{array}$ & $\begin{array}{c}\text { seasonal } \\
\text { population }\end{array}$ & $\begin{array}{c}\text { Beach } \\
\text { impact } \\
\text { factor (I) }\end{array}$ \\
\hline Argostoli & 10 & 12.589 & 2.386 & 2.889 & 5.275 & 17.864 & 1786,4 \\
\hline Eleiou Pronon & 6 & 3.840 & 2.014 & 3037 & 5.051 & 8.891 & 1481,83 \\
\hline Erisoou & 4,5 & 1.963 & 432 & 835 & 1.267 & 3.230 & 1.65 \\
\hline Livathous & 4 & 4.663 & 1.478 & 2.787 & 4.265 & 8.928 & 2232 \\
\hline Palikis & 6 & 7.836 & 1.889 & 1.092 & 2.981 & 10.817 & 1802,83 \\
\hline Sami & 3 & 2.895 & 592 & 771 & 1.363 & 4.258 & 1419,33 \\
\hline Pilareon & 1,5 & 1.565 & 191 & 600 & 791 & 2.356 & 1570,67 \\
\hline $\begin{array}{c}\text { Community of } \\
\text { Omaloi }\end{array}$ & - & 1.053 & 0 & 25 & 25 & 1.078 & 0 \\
\hline Cephalonia island & 35 & 39.488 & 8.986 & 12.032 & 21.018 & 60.506 & 1728.74 \\
\hline Ithaca island & 3 & 3.084 & 195 & 959 & 1.154 & 4.238 & 1412,67 \\
\hline $\begin{array}{c}\text { Prefecture of } \\
\text { Cephalonia }\end{array}$ & 38 & 39.488 & 9.181 & 12.991 & 22.172 & 61.660 & 1622,3 \\
\hline
\end{tabular}

\subsection{Beach impact factor}

With this indicator we analyse the pressures facing the coastal environment, as they describe the concentration of people visiting and using the facilities of the coastal area, and especially beaches. From the data presented in Table 8, a beach impact factors of 1,7 persons per metre of beach and 1.6 persons per metre of beach were calculated for Cephalonia and Ithaca respectively. It is clear that both islands do not face serious pressure as other Greek islands do. From our previous studies Rhodes and Kos attain 2,8 and 2,18 persons per metre of beach, respectively. The quality of bathing water is high for both islands, as Cephalonia has 7 Blue Flags. Ithaca does not have any beaches with Blue Flag certification, a result that agrees with other indicators that show low tourist development.

In Ithaca island no environmental pollution incidents have occurred during the period of 1993 to 2007 [13]. Data concerning environmental incidents in seas and Cephalonia coastal waters, from Hellenic Coast Guard are presented in the table above. Different causes are highlighted above. Most of the incidents come from maritime pollution. 
Table 9: $\quad$ Ports and marinas in the Prefecture of Cephalonia (nine ports operate in Cephalonia, whereas in Ithaka the number of ports is five). None have environmental management systems.

\begin{tabular}{|c|c|c|c|}
\hline PORTS IN CEPHALONIA AND ITHACA & 1 \\
\hline Municipalities & & Sami & 1 \\
\hline Argostoli & 1 & Pilareon & 0 \\
\hline Eleiou Pronon & 0 & Community of Omaloi & 9 \\
\hline Erisou & 2 & Cephalonia island & 5 \\
\hline Livathous & 1 & Ithaca island & 5 \\
\hline Palikis & 3 & Prefecture of Cephalonia & 14 \\
\hline
\end{tabular}

Table 10: $\quad$ Shore and marine pollution in Cephalonia Island [12].

\begin{tabular}{|c|c|c|c|c|c|}
\hline \multicolumn{6}{|c|}{ POLLUTION TO CEPHALONIA SHORE AND SEAS } \\
\hline Municipalities & $\begin{array}{c}\text { pollution due } \\
\text { to bars and } \\
\text { restaurants }\end{array}$ & $\begin{array}{l}\text { pollution due } \\
\text { to hotels }\end{array}$ & $\begin{array}{l}\text { maritime } \\
\text { pollution }\end{array}$ & $\begin{array}{c}\text { pollution due to } \\
\text { olive oil press }\end{array}$ & $\begin{array}{c}\text { Pollution due } \\
\text { to dairy } \\
\text { factories }\end{array}$ \\
\hline 1997 & 1 & 0 & 1 & 0 & 0 \\
\hline 1998 & 0 & 1 & 2 & 0 & 0 \\
\hline 1999 & 0 & 0 & 1 & 2 & 0 \\
\hline 2000 & 0 & 0 & 0 & 0 & 1 \\
\hline 2001 & 0 & 0 & 0 & 0 & 0 \\
\hline 2002 & 1 & 0 & 0 & 0 & 0 \\
\hline 2003 & 0 & 0 & 1 & 0 & 0 \\
\hline 2004 & 1 & 0 & 1 & 0 & 0 \\
\hline 2005 & 0 & 0 & 1 & 0 & 0 \\
\hline 2006 & 0 & 0 & 2 & 0 & 0 \\
\hline
\end{tabular}

Table 11: $\quad$ Protected areas in Cephalonia [14].

\begin{tabular}{|c|c|c|c|c|}
\hline GR2220001 & $\mathrm{SCI}$ & $\begin{array}{l}\text { KALON MOUNTAIN } \\
\text { CEPHALONIA }\end{array}$ & $\begin{array}{l}\text { Mountainous area with } \\
\text { unique fauna and flora }\end{array}$ & 2566,19 \\
\hline GR2220002 & SCI \& SPA & AIMOS NATIONAL PARK & Abies cephallonica forests & 2779,43 \\
\hline GR2220004 & $\mathrm{SCI}$ & $\begin{array}{ll}\text { COAST ZONE } & \text { ARGOSTOLI } \\
\text { EOS } & \text { VLACHATA } \\
\text { (CEPHALONIA } & \& \text { ORMOS } \\
\text { MOUNTA } & \\
\end{array}$ & $\begin{array}{l}\text { Important area for dolphins } \\
\text { and seals }\end{array}$ & 3763,52 \\
\hline GR2220005 & SCI & $\begin{array}{lr}\text { CEPHALONIA } & \text { WEST } \\
\text { COASTS AND NORTH } \\
\text { ITHAKI COASTS } \\
\text { (CAPES: GERO GOMPOS - } \\
\text { DRAKOU PIDIMA - KENTRI } \\
\text { - AG. IOANNIS) }\end{array}$ & $\begin{array}{l}\text { Important area for dolphins } \\
\text { and seals }\end{array}$ & 18682,16 \\
\hline
\end{tabular}

\subsection{Natural environment}

The island of Cephalonia is mountainous (more than the other Ionian islands), with peaks running from the most northerly cape (Dafnoudi) to the extreme south (cape Mounda). Mt Ainos, popularly called "Megalo Vouno" (the big mountain) is covered by very rare species of fir tree (Abies cephalonensis) and and the semi-wild pony of Kefalonia. Another 10 mountains are scattered around the island. The mountain of Ainos is one of the national parks in Greece due to the local flora, accompanied by some mountainous areas, as well as marine and coastal areas, all belonging to the NATURA 2000 network.

These environmentally protected areas, based on the "Natura" program do not, as yet, have a management scheme and are not governed by a specific 
establishment or organization. The National Park of Ainos in Cephalonia has a acquired a management body since 2007 .

\subsection{Garbage and waste management}

Urban waste management (solid and liquid) on all the islands is characterized by lack of efficiency. Only the large urban centres fulfil the basic requirements of modern waste management installations. It is interesting to note that other smaller settlements do not even have a complete urban waste collection network.

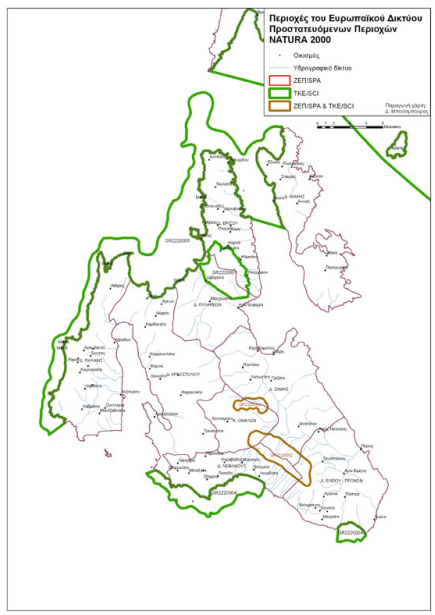

Figure 6: Environmentally protected areas in Cephalonia.

Table 12: Urban waste and garbage management in Cephalonia and Ithaca islands.

\begin{tabular}{|c|l|l|l|l|}
\hline \multicolumn{5}{|c|}{ URBAN WASTE AND GARBAGE MANAGEMENT } \\
\hline & Inhabitants & $\begin{array}{l}\text { Urban waste } \\
\text { treatment plant }\end{array}$ & $\begin{array}{l}\text { Percentage of } \\
\text { waste treated }\end{array}$ & Garbage management \\
\hline Argostoli & 12589 & YES & $80 \%$ & Place of sanitary burial \\
\hline Eleiou Pronon & 3840 & NO & 0 & Place of sanitary burial \\
\hline Erisoou & 1963 & YES & $5 \%$ & Place of sanitary burial \\
\hline Livathous & 4663 & NO & 0 & Place of sanitary burial \\
\hline Palikis & 7836 & YES & $40 \%$ & Place of sanitary burial \\
\hline Sami & 2895 & YES & $60 \%$ & Place of sanitary burial \\
\hline Pilareon & 1565 & NO & 0 & Place of sanitary burial \\
\hline Community of Omaloi & 1053 & NO & 0 & Place of sanitary burial \\
\hline Cephalonia island & 39.488 & 19.951 & $50 \%$ & Place of sanitary burial \\
\hline Ithaca island & 3084 & NO & 0 & $\begin{array}{l}\text { Transferred in place of } \\
\text { sanitary } \\
\text { Cephalonia }\end{array}$ \\
\hline Prefecture of Cephalonia & 42.572 & 19.951 & $45 \%$ & Place of sanitary burial \\
\hline
\end{tabular}




\section{Conclusions}

In this paper we present selected carrying capacity assessment indicators for Cephalonia and Ithaca islands that differ in their tourist development, as well as draw some conclusions as to how these indicators can assist in developing sustainable tourist development policies, in island settings.

Calculated coastline impact indicators, indicate that the island of Cephalonia faces the same pressure on its coastal regions $(1,7 \mathrm{people} / \mathrm{m}$ of beach) as Ithaca $(1,4)$. Comparing these measures to other islands of Dodecaneese archipelago, Rhodes faces a similar pressure $(1,3)$, whereas Kos with 2 persons $/ \mathrm{m}$ of beach is more congested [15].

Cephalonia tourist product is based on the classical tourism model, relying on sea and beach activities. Alternative tourist services and activities in Cephalonia are slowly acquiring some momentum as there is a pilot alternative tourist village open to visitors; seems that such businesses represent the future for tourist development so far as the international demand for alternative tourism and the needs for the environmental protection are concerned.

Environmental indictors, indicate that the transformation from a low quality, high numbers tourist trade, to an alternative, high quality one, will not be easy, since waste management systems are insufficient in dealing with urban and solid waste. It is well known that, such inadequacies have serious environmental consequences, and hinder any attempts towards developing a tourist industry based on quality. The coverage of urban waste treatment plants in Cephalonia and Ithaca is lower than $50 \%$ of the needs.

Cephalonia hosts 4 environmentally protected areas. The increasing public interest in nature and landscape preservation is, today, considered a major positive factor in the tourist development process. It is true that the growing influx of visitors can exert strong pressures on fragile ecosystems [16]. Natura 2000 Network areas are a step in the right direction, but must be supported with effective management schemes[17] and be run under a modern and highly sophisticated regime.

Tourist development indicators for Cephalonia and Ithaca lead us to conclude that the tourist industry should aim at extending the tourist season to include more months, attain occupancy well over $50 \%$ for April, May, September and October, and probably more visitors with varied interests and expectations of Cephalonia and Ithaca.

Planning is conceptually related to sustainable development [18]. It includes approaches to deal with development and economic options, to prevent environmental damage and to involve public and stakeholders in decisionmaking processes. It is proposed that serious efforts have to be made in the direction of formulating viable policies and developing tools for effective implementation and control [19].

\section{Acknowledgements}

We would like to thank Dimitra Tselou, economist, University of Piraeus, Spyros Gavanozis Hellenic Civil Aviation Authority, Nikos Matzavinos, and 
Ernestos Tzanatos Professor, University of Piraeus for their help and collaboration:

\section{Reference}

[1] UNEP/MAP/PAP, 1997

[2] Coccosis H and Mexa A, 'The challenge of Tourism Carrying Capacity Assessment', Ashgate 2004

[3] Fernando J Garrigós Simón, Y. Narangajavana, and D. Palacios-Marqués. 'Carrying capacity in the tourism industry: a case study of Hengistbury Head'

[4] "Tourist Guide of Greece", Greece Tourist Information, Athens 2008

[5] Greece only the best, Kyritsis publishing, Athens 2000

[6] "Cephalonia and Ithaca", Toubi's publications, Athens 1995

[7] Jurincic I 'Carrying capacity assessment of Slovene Istria for tourism', $2^{\text {nd }}$ International Conference on sustainable planning and development Bologna 2005, Wessex Institute of Technology

[8] Zannou V, 'Guide of Socio-Economic Studies for the Integrated Management of the Water Environment' 1999

[9] Greenpeace, August 2007

[10] Hellenic ministry of environment 2007-Google Erath 21-4-08

[11] Union of Hotel Owners of Cephalonia September-07-April 08

[12] Hellenic Coast Guard, Port Authority of Cephalonia 16-10-07

[13] Hellenic Coast Guard, Port Authority of Ithaca 9-1-08

[14] Ministry of Environment, www.minenv.gr

[15] Prokopiou DG -Tselentis BS Bousbouras D. and Toanoglou M "Carrying capacity assessment in tourism: The case of Dodecanese archipelago", The Ravage of the planet, First International Conference on the Management of Natural Resources, Sustainable Development and Ecological Hazards, Bariloche- Argentina 2006, Wessex Institute of Technology UKUniversity of Siena, Italy 12 - 14 December 2006 Bariloche, Argentina

[16] Papayanis T, 'Tourism carrying capacity in areas of ecological importance'

[17] Prokopiou DG and Tselentis BS 'Proposals for sustainable development and Environmental protection for the island of Rhodes', Rhodes 2003 (in Greek)

[18] T. Fidelis, "Integrating environmental issues into the Portuguese planning system- 10 years of emerging challenges and persistent problems" Conference on sustainable planning and development Bologna 2005, Wessex Institute of Technology

[19] Prokopiou DG, Tselentis BS, Bousbouras D. and Toanoglou M. "Environmental impacts caused by the tourist industry in Elafonisos Island and the Neapoli district, Greece" ECOSUD 2007,Sixth International Conference on Ecosystems and Sustainable Development, Organised by: Wessex Institute of Technology, UK -The University of Coimbra, PortugalThe University of Siena, 4 - 6 September 2007 Coimbra, Portugal 